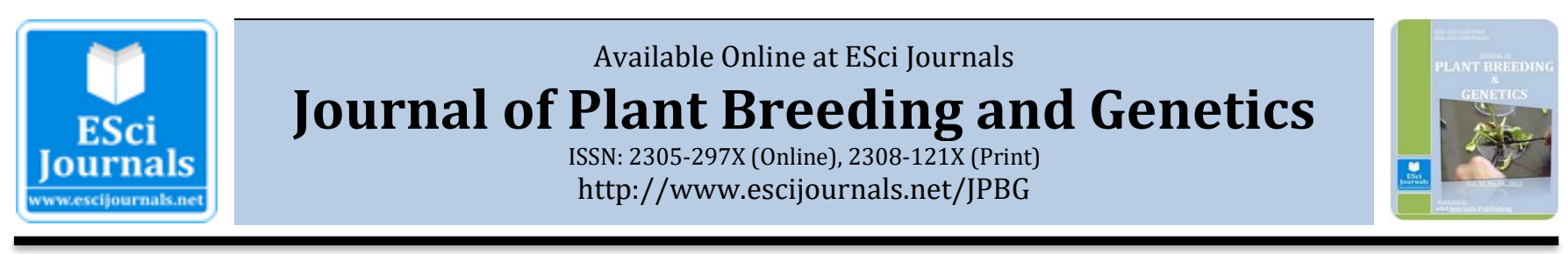

\title{
GENETIC EFFECTS OF RESISTANCE TO SPOT BLOTCH IN SELECTED WHEAT GENOTYPES
}

\author{
a,bBatiseba Tembo*, bJulia Sibiya, cPangirayi Tongoona, ${ }^{\mathbf{b}}$ Rob Melis \\ a Zambia Agricultural Research Institute (ZARI), Mt. Makulu Research Station, P/B7, Chilanga, Zambia. \\ ${ }^{b}$ African Centre for Crop Improvement, University of KwaZulu-Natal, College of Agriculture, Engineering and Science, School \\ of Agricultural, Earth and Environmental Sciences, Private Bag X01, Scottsville 3209, Pietermaritzburg, South Africa. \\ ${ }^{c}$ West African Centre for Crop Improvement, University of Ghana, PMB 30 Legon, Ghana.
}

\section{A B S T R A C T}

Spot blotch disease of wheat (Triticum aestivum L.) caused by Bipolaris sorokiniana (Sacc) Shoemaker causes significant yield and quality losses in warm and humid agro-ecologies of the world. Breeding for resistance is considered to be the most economical and sustainable approach of controlling the disease. The objective of this study was to determine the genetic effect influencing inheritance of resistance to spot blotch in selected wheat genotypes using generation mean analysis to devise a resistance breeding strategy. Populations involving six generations (P1, P2, F1, F2, BCP1 and BCP2) were developed comprising two selected parental lines, i.e., Loerrie II and 19HRWSN6. Test materials were field evaluated for resistance to spot blotch during the 2014/15 cropping season in Zambia. Additive genetic effects were significant and accounted for $94.79 \%$ of the total genetic variation for spot blotch resistance in wheat. Dominance and epistatic effects were not detected. The predominance of additive genetic effects suggests that recurrent selection strategy could boost spot blotch resistance in these population to develop pure line wheat cultivars.

Keywords: additive genetic effect, dominance, epistasis, generation mean analysis, wheat.

\section{INTRODUCTION}

Spot blotch disease (Figure 1) caused by Bipolaris sorokiniana (Sacc.) Shoemaker is the major fungal disease affecting wheat production in the warm and humid environments worldwide. The pathogen infects all plant parts, thus resulting in reduced yield and quality due to shrivelled grains. Yield loss reaching up to $100 \%$ on susceptible cultivars has been reported in Zambia due to the disease (Muyanga, 1995). Various control methods (crop rotation, removing of diseased leaves and use of chemicals) are used to reduce damage caused by the disease. However, these have not been either effective, practical or economical. Breeding for resistance is considered to be the most viable, economical and sustainable approach to reducing losses caused by the disease.

Knowledge on the genetics of spot blotch resistance is

* Corresponding Author:

Email: batemfe@yahoo.com

(C) 2018 ESci Journals Publishing. All rights reserved. required for effective resistance breeding against the disease (Ajith and Anju, 2005; Eshghi and Akhundova, 2009; Zaazaa et al., 2012). Previous studies on the type of gene action controlling inheritance of resistance to spot blotch disease have reported conflicting reports (Joshi et al., 2004b; Prashant and Kumar, 2010). Prashant and Kumar (2010) and Neupane et al. (2007) reported that resistance to spot blotch disease was dominant and controlled by one major gene. Duveiller and Sharma (2009) suggested that dominant, recessive and epistatic gene effects governed the inheritance of resistance to the disease. Similarly, studies by Ragiba et al. (2004) indicated the importance of the dominant and recessive gene in conditioning resistance. Singh et al. (1998) showed two recessive genes responsible for governing inheritance of resistance to the disease. Sharma et al. (2006) found that partially dominant genes controlled the inheritance of resistance and that resistance was inherited quantitatively with moderate to high heritability estimates. Conversely, 
Joshi et al. (2004a) indicated the presence of three additive genes controlling the inheritance of resistance. It is clear that more information about the inheritance of resistance and the type of gene action controlling resistance to spot blotch is required for the successful spot blotch resistance breeding of wheat. The objective of this study was to determine the genetic effect influencing inheritance of resistance to spot blotch in selected wheat genotypes using generation mean analysis to devise a resistance breeding strategy.

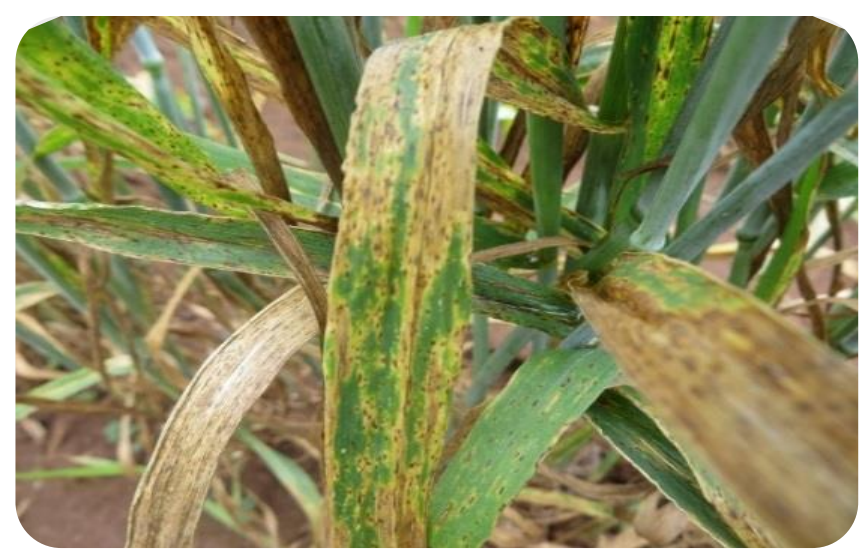

Figure 1. Spot blotch disease on wheat.

\section{MATERIALS AND METHODS}

Plant materials and crosses: Two parental wheat genotypes (19HRWSN6 and Loerrie II) contrasting for resistance to spot blotch, were crossed to generate F1 population in 2013 off-season (May-September) under irrigation at Mt. Makulu Research Station in Zambia. 19HRWSN6 (Kenya Heroe, (P1)) is an introduced genotype from the International Maize and Wheat Improvement Centre (CIMMYT) - Mexico. It is resistant to spot blotch, has white grain type and adapted to high rainfall regions. Loerrie II (P2) is a red grain type genotype obtained from Zambia. It is high yielding, locally adapted and susceptible to spot blotch.

Hand emasculation and pollination was used for crossing the wheat lines. The F1 plants were advanced to F2 by self-pollination. The F1 plants were also crossed to the resistant parent (P1) and susceptible parent (P2) to produce backcross generations $\mathrm{BCP} 1$ and $\mathrm{BCP} 2$, respectively. Thus, six generations were developed consisting of two parents, F1, F2, BCP1 and BCP2.

Experimental sites: The experiment was conducted in Zambia in Mpongwe, Copperbelt Province (120ㅜ․622' S, 28⒕660' E, 1700 m) and Mt. Makulu Research Station, in Chilanga, Lusaka Province (153․946' S, 28o⒖078' E, $1300 \mathrm{~m}$ ). Mpongwe receives over $1000 \mathrm{~mm}$ of rainfall while Mt. Makulu receives rainfall between 800 - 1000 $\mathrm{mm}$ rainfall during the crop growing season (Bunyolo et al., 1997) Evaluation of genotypes was done under natural conditions.

Field establishment and experimental design: The six generations $\mathrm{P} 1, \mathrm{P} 2, \mathrm{~F} 1, \mathrm{~F} 2$ and $\mathrm{BCP} 1$ and $\mathrm{BCP} 2$ were planted using a randomised complete block design with two replications with the parents and F1 consisting of one row each, an F2 population with six rows and BCP1 and BCP2 families with four rows each. Each row was 3 $\mathrm{m}$ long with an inter-row spacing of $20 \mathrm{~cm}$ and intra-row spacing of $10 \mathrm{~cm}$. Each row was planted with 60 seeds which were later thinned keeping 30 plants per row. Early planting (8- 9 November 2014) was done to enhance disease spread during flowering. To create enough disease pressure on to the plants, one row of Sonalika, spot blotch susceptible wheat variety, was planted as spreader row in the alleyways and borders. Standard agronomic practices were followed for good crop management. Weeding was done using hand hoes.

Disease assessment: Disease severity was estimated visually based on foliar symptoms. All plants were scored for disease severity using a 0-9 scale based on Saari and Prescott's scale for assessing foliar disease at Zadoks' stage ZGS77 (Eyal et al., 1987). The genotypes were classified using the criterion proposed by Chaurasia et al. (1999). Genotypes falling in the 1-3 category were recorded as resistant, 4 as moderately resistant, 5-6 moderately susceptible and 7-9 as susceptible.

Data analysis: The data collected was subjected to combined analysis of variance using the general linear model procedure (PROC GLM) in SAS version 9.3 (SAS Institute, 2011) to determine whether there were significant differences. The model used was;

$$
Y i j k=\mu+G i+E j+G \times E+r k(E)+e i j k
$$

Where Yijk $=$ spot blotch disease score of $\mathrm{i}^{\text {th }}$ generation in $\mathrm{j}^{\text {th }}$ environment of $\mathrm{k}^{\text {th }}$ replication, $\mu=$ overall mean, gi= generation mean, $\mathrm{Ej}=\mathrm{j}^{\text {th }}$ environment, $\mathrm{G} \times \mathrm{E}=$ generation $\times$ environment interaction, $\mathrm{rk}=\mathrm{k}^{\text {th }}$ replication within $\mathrm{E}$ environment and eijk= residual factor.

Mean separation between generations was done in SAS version 9.3 (SAS Institute, 2011) using least significance difference (LSD) procedure for pairwise comparison (P $\leq$ 0.05) as suggested by Kang (1994). 
Data was subjected to generation mean analysis (GMA) using the methodology proposed by Mather and Jinks (1971) following analysis of variance. The GMA was performed using PROC GLM and PROC REG procedures in accordance with SAS macros described by Kang (1994). The genetic model used was;

$$
\mathrm{Y}=\mathrm{m}+\alpha \mathrm{a}+\beta \mathrm{d}+\alpha^{2} \mathrm{aa}+2 \alpha \beta \mathrm{ad}+\beta^{2} \mathrm{dd}
$$

Where;

$\alpha$ and $\beta$ are the coefficients for a and d, respectively

$\mathrm{Y}=$ generation mean

$\mathrm{m}=$ mean of the $\mathrm{F} 2$ generation as the base population

and intercept value

$\mathrm{a}=$ additive effects

$\mathrm{d}=$ dominance effects

$\mathrm{aa}=$ additive $\mathrm{x}$ additive gene interaction effects

$\mathrm{ad}=$ additive $\mathrm{x}$ dominance gene interaction effects

$\mathrm{dd}=$ dominance $\mathrm{x}$ dominance gene interaction effects

A stepwise linear regression was used to estimate the additive and dominant parameters. The regression analysis was carried out using PRO REG macros in SAS developed by Kang (1994). The regression analysis was weighted based on the inverse of the variance of means and matrix parameter (Checa et al., 2006). To establish the parameters that were acceptable within the model, $\mathrm{R}^{2}$ and F-test (goodness of- fit) were used (Ceballos et al., 1998). The F-test was calculated using the formula below (Checa et al., 2006):

$\mathrm{Fc}=[(\mathrm{SSq}$ general model $)-(\mathrm{SSq}$ reduced model)/difference in df] divided by SSq residual from the general model/df residual from the general model

SSq residual from the general model/df residual from the general model

Where

$\mathrm{SSq}=$ sums of squares, $\mathrm{df}=$ degrees of freedom, $\mathrm{Fc}=\mathrm{F}$ calculated

To determine the importance of additive, dominance or epistatic effects, the model's parameters were tested sequentially one at a time starting with additive effects and then in combination with other parameters of the model (Ceballos et al., 1998). The importance of the gene effect estimates was based on the ratio between the sums of squares and the total sums of the square after entering the different elements in the model. The significance of the genetic estimates was determined by dividing the estimated parameter values with their standard errors, if the value exceeded 1.96 then it was considered significant
(Singh and Chaudhary, 1995).

Variance components (additive, dominance or environmental) were estimated as described by Mather and Jinks (1971) using the equation below;

$$
\begin{aligned}
& A=\left(2 \sigma^{2} F 2\right)-\sigma^{2} B C P 1+\sigma^{2} B C P 2 \\
& D=\sigma^{2} G(F 2)-\sigma^{2} A(F 2) \\
& E=1 / 4\left(\sigma^{2} P 1+\sigma^{2} P 2+\left(2 \sigma^{2} F 1\right)\right.
\end{aligned}
$$

Where: $\mathrm{A}=$ Additive genetic variance, $\mathrm{D}=$ Dominance variance and $\mathrm{E}=$ Environmental component of variance Where: $\sigma^{2} \mathrm{P} 1=$ variance of parent $1 ; \sigma^{2} \mathrm{P} 2=$ variance of parent $2 ; \sigma^{2} \mathrm{~F} 1=$ variance of $\mathrm{F} 1 ; \sigma^{2} \mathrm{~F} 2=$ variance of $\mathrm{F} 2$ generation; $\sigma^{2} \mathrm{BCP} 1=$ variance of backcross to parent 1 ; $\sigma^{2} \mathrm{BCP} 2=$ variance of backcross to parent 2 .

Narrow sense heritability $\left(\mathrm{h}^{2}\right)$ was estimated as follows; (Warner, 1952).

$\mathrm{h}^{2}=\left[\sigma^{2} \mathrm{~F} 2-\left(\sigma^{2} \mathrm{BCP} 1+\sigma^{2} \mathrm{BCP} 2\right) / 2\right] / \sigma^{2} \mathrm{~F} 2$.

Where, $\sigma^{2} \mathrm{~F} 2=$ variance of $\mathrm{F} 2$ generation, $\sigma^{2} \mathrm{BCP} 1=$ variance of backcross to parent $1 ; \sigma^{2} \mathrm{BCP} 2=$ variance of backcross to parent 2 .

The coefficient of dominance (F) was calculated by the formula: (Mather and Jinks, 1971).

$\mathrm{F}=\sigma^{2} \mathrm{BCP} 2-\sigma^{2} \mathrm{BCP} 1$

\section{RESULTS}

Analysis of variance of spot blotch disease severity: The analysis of variance (Table 1) revealed highly significant differences among generations for resistance to spot blotch disease $(\mathrm{P}<0.001)$. Environments and generation $x$ environment interaction were not significantly different $(\mathrm{P}>0.05)$ for spot blotch disease severity.

Table 1: Analysis of variance showing degrees of freedom, mean squares and significance tests of six generations of Loerrie II $\times 19$ HRWSN6 cross evaluated across two testing environments in Zambia during 2014/15 cropping season.

\begin{tabular}{lcc}
\hline Source of variation & $\begin{array}{c}\text { Degree of } \\
\text { freedom }\end{array}$ & Mean square \\
\hline ENV & 1 & $0.26^{\text {ns }}$ \\
Rep (ENV) & 2 & 13.74 \\
Generation (G) & 5 & $2.90^{* * *}$ \\
G× ENV & 5 & $0.18^{\text {ns }}$ \\
Error & 10 & 2.33 \\
Corrected total & 23 & \\
Overall mean & 5.84 & \\
CV $(\%)$ & 8.1 & \\
$\mathrm{R}^{2 \%}$ & 94.87 & \\
\hline
\end{tabular}

*** Significant at $\mathrm{p}<0.001, \mathrm{~ns}=$ not significant; $\mathrm{ENV}=$ Environment; Rep=Replication. 
Mean spot blotch disease severity of populations: The means of spot blotch disease severity score for the six generations of Loerrie II $\times 19$ HRWSN 6 cross are presented in Table 2 . The F1 population had less disease compared to P1, F2, BCP1 and BCP2 but not with P2 (resistant parent). The F2 generations had a mean severity score less than the mean of the susceptible parent (P1). Nonetheless, non-significant differences were observed between the means of the susceptible parent P1, BCP1, BCP2 and F2 generations (Table 2). The means of the $\mathrm{F} 2$ generations were not significantly different from the means of F1. Table 2 also shows that the F1 was significantly different from P1 and BCP1. The resistant parent $\mathrm{P} 2$ was significantly different from $\mathrm{F} 1$ and P1, F2, BCP1 and BCP2 generations.

Generation mean analysis: The analysis of variance for generation means for spot blotch disease reaction (Table 3) revealed highly significant differences for additive gene effects $(\mathrm{P}<0.001)$. The additive gene effects accounted for $94.79 \%$ of the total genetic variation. The dominance, additive $\times$ additive, additive $\times$ dominance and dominance $\times$ dominance effects were non- significant $(\mathrm{P}>0.05)$. Dominance effects explained $1.19 \%$ of the total variation (Table 3 ). Additive $\times$ dominance gene interaction contributed most of the total genetic variation (5.34\%) amongst other epistasis gene interaction.

Table 2: Generations of means of spot blotch disease severity scores of six generation of Loerrie II $\times$ 19HRWSN6 cross evaluated over two locations in Zambia during 2014/15 cropping season.

\begin{tabular}{cc}
\hline Generation & Mean \\
\hline P1 & $6.68 \mathrm{a}$ \\
BCP1 & $6.54 \mathrm{a}$ \\
F2 & $6.34 \mathrm{ab}$ \\
BCP2 & $5.99 \mathrm{ab}$ \\
F1 & $5.73 \mathrm{~b}$ \\
P2 & $4.36 \mathrm{c}$ \\
LSD (5\%) & 0.76
\end{tabular}

P1= Loerrie II (susceptible parent), P2=19HRWSN6 (resistant parent). Means followed by the same letter in a column are not significantly different at $\mathrm{P}<0.05$.

Table 3: Mean squares of gene effects for spot blotch scores and the relative contribution of gene effects to the model total sums of square of Loerrie II $\times 19$ HRWSN6 cross evaluated at Mpongwe and Mt. Makulu sites during 2014/15 cropping season.

\begin{tabular}{lcc}
\hline Source of variation & Mean Square & The relative contribution of gene effects (\%) \\
\hline Replication & $26.83^{* *}$ & - \\
Additive (a) & $10.81^{* * *}$ & 94.79 \\
Dominance (d) & $0.14^{\mathrm{ns}}$ & 1.19 \\
Additive $\times$ additive (aa) & $0.01^{\mathrm{ns}}$ & 0.12 \\
Additive $\times$ dominance (ad) & $0.61^{\mathrm{ns}}$ & 5.34 \\
Dominance $\times$ dominance $(\mathrm{dd})$ & $0.38^{\mathrm{ns}}$ & 3.34 \\
\hline
\end{tabular}

${ }^{* * *}$ highly significant $\mathrm{p}<0.001,{ }^{* *}$ significant $\mathrm{p}<0.01$; ns= not significant.

Gene effects of spot blotch resistance: The results summarized in Table 3 did not give any evidence for epistasis, hence, the additive-dominance model was used with the following three parameters: mean $(\mathrm{m})$, additive (a) and dominance (d). The gene effects estimate of (m), (a) and (d) are as presented in Table 4. The mean effect was highly significant $(\mathrm{P}<0.001)$ while the additive effect was significant at $\mathrm{P}<0.01$. The dominance effect was not significant. It was also observed that the additive effects were higher in magnitude than the dominance.

The narrow sense heritability estimate was moderately high (55.45\%). The coefficient of the degree of dominance was found to be negative and less than unity $(-0.07)$.
Table 4: Estimates of genetic effects $( \pm$ SE) fitted to a three parameter model for resistance to spot blotch for the Loerrie II $\times 19$ HRWSN6 cross.

\begin{tabular}{cc}
\hline Model & Gene effects estimates \\
\hline Mean $(\mathrm{m})$ & $5.60 \pm 0.43^{* * *}$ \\
Additive (a) & $1.26 \pm 0.43^{* *}$ \\
Dominance $(\mathrm{d})$ & $1.13 \pm 0.99^{\mathrm{ns}}$ \\
\hline *** &
\end{tabular}

$* * *$, and ${ }^{* *}$ indicate significance at $\mathrm{P}<0.001$ and $\mathrm{P}<0.01$, respectively. $n s=$ not significant; $\mathrm{SE}=\mathrm{Standard}$ error.

\section{DISCUSSION}

The significant differences established from the analysis of variance involving the following six generations: P1, 
P2, F1, F2, BCP1 and BCP2 revealed differential responses to spot blotch disease, indicating the contrast between the progenitors, P1 and P2, which is a requirement for GMA. The mean disease severity score of the susceptible and resistant parent were different from the means of F1 and F2. Additionally, the mean comparisons revealed significant differences between the parental genotypes. Furthermore, the means of BCP1 and BCP2 tended to be closer to the respective recurrent parent indicating the divergence of the parents which further satisfied the basic prerequisite for generation mean analysis (Mather and Jinks, 1971).

The resistant parent, $\mathrm{P} 2$, showed resistant reaction to spot blotch disease due to the low disease severity score observed. For this reason, P2 could be identified as a good source of resistance. The mean disease severity of F1 was in between the parental genotypes, suggesting partial dominance (Checa et al., 2006). The coefficient of dominance $\mathrm{F}$ was negative and nearly zero implying that the dominant genes were low in 19HRWSN6, the resistant parent (Mohamed, 2014). According to the mean comparison, the mean of BCP1 and BCP2 were not significantly different. Nevertheless, it was observed that backcross breeding method could provide a useful means of improving resistance to spot blotch disease because BCP2 had disease severity scores lower than the susceptible parent indicating a reduction in the disease in each backcross.

The additive gene effects were significant and positive showing that they were important in controlling resistance to spot blotch disease. Besides, the higher magnitude of the contribution of additive effects $(94.79 \%)$ to the total variation of generation further indicated a much larger role of additive effects in the inheritance of resistance to spot blotch disease compared to dominance genetic effects. Sharma et al. (2006) reported similar findings. This suggests that the resistance levels in wheat genotypes could be improved through simple mass selection in early segregating generations (Mumtaz et al., 2015). Furthermore, the predominance of additive gene effects indicates that recurrent selection for spot blotch resistance could be effective. The narrow sense heritability was moderately high $(55.45 \%)$ revealing a large contribution of additive effects in controlling resistance to spot blotch disease. Moderate narrow sense heritability estimates for spot blotch disease agreed well with earlier reports by Sharma et al. (1997b) and Sharma et al. (1997a). In this study non-allelic interactions were found not important in controlling resistance to spot blotch disease, suggesting that selection for resistance to spot blotch disease is possible in early segregating generations. The resistant parent, 19HRWSN6, could further be incorporated in breeding programmes to improve resistance to spot blotch disease.

\section{CONCLUSION}

Additive gene effects were important in the inheritance of resistance to spot blotch in selected wheat genotypes. This was further confirmed by moderate high narrowsense heritability estimates which suggests a great involvement of additive gene effects in the expression of resistance to the disease. Epistasis had no effect in the control of resistance to spot blotch disease.

\section{ACKNOWLEDGEMENTS}

The Alliance for a Green Revolution in Africa (AGRA) is sincerely thanked for supporting the work through a PhD scholarship to the first author.

\section{REFERENCES}

Ajith, P. M. and P. M. Anju. 2005. Generation mean analysis of yield and anthracnose resistance in chilli (Capsicum annuum L.). Vegetable Science, 32: 76-77.

Bunyolo, A., B. Chirwa and M. Muchinda. 1997. Agroecological and climatic conditions, In: S.W. Muliokela, (ed.), Zambia seed technology handbook. Berlings, Arlov, Sweden, p. 19-27.

Ceballos, H., S. Pandey, L. Narro and J. C. PerezVelázquez. 1998. Additive, dominant, and epistatic effects for maize grain yield in acid and non-acid soils. TAG Theoretical and Applied Genetics, 96: 662-668.

Chaurasia, S., A. Joshi, R. Dhari and R. Chand. 1999. Resistance to foliar blight of wheat: a search. Genetic Resources and Crop Evolution, 46: 469475.

Checa, O., H. Ceballos and M. W. Blair. 2006. Generation Means Analysis of Climbing Ability in Common Bean (Phaseolus vulgaris L.). Journal of Heredity, 97: 456-465.

Duveiller, E. and R. Sharma. 2009. Genetic improvement and crop management strategies to minimize yield losses in warm nontraditional wheat growing areas due to spot blotch pathogen Cochliobolus sativus. Journal of Phytopathology, 157: 521-534.

Eshghi, R. and E. Akhundova. 2009. Genetic analysis of grain yield and some agronomic traits in hulless 
barley. African Journal of Agricultural Research, 4: 1464-1474.

Eyal, Z., A. L. Scharen, J. M. Prescott and M. van Ginkel. 1987. The Septoria diseases of wheat: Concepts and methods of disease management. D.F. CIMMYT, Mexico, p. 18-28.

Joshi, A. K., S. Kumar, R. Chand and G. Ortiz-Ferrara. 2004a. Inheritance of resistance to spot blotch caused by Bipolaris sorokiniana in spring wheat. Plant Breeding, 123: 213-219.

Joshi, S. K., S. N. Sharma, D. L. Singhania and R. S. Sain. 2004b. Combining ability in the F1 and F2 generations of diallel cross in hexaploid wheat (Triticum aestivum L. em. Thell). Hereditas, 141: 115-121.

Kang, M. S. 1994. Applied quantitative genetics. Department of Agronomy, Louisiana State University, Baton Rouge, pp. 157.

Mather, K. and J. L. Jinks. 1971. Biometrical genetics 4th ed., Cornell University Press, Ithaca, New York, USA.

Mohamed, N. 2014. Genetic Control for Some Traits Using Generation Mean Analysis in Bread Wheat (Triticum aestivum L.). International Journal of Plant \& Soil Science, 3: 1055-1068.

Mumtaz, A., F. Zafar and S. Saifulmalook. 2015. A review on mating designs. Nature and Science 13: 98-105.

Muyanga, S. 1995. Production and research review of small cereals in Zambia. Breeding for disease resistance with emphasis on durability. Proceedings of a regional workshop for eastern, central and southern Africa, held at Njoro, Kenya, October 2-6, 1994. Landbouwuniversiteit Wageningen (Wageningen Agricultural University), p. 60-64.

Neupane, R. B., R. C. Sharma, E. Duveiller, G. OrtizFerrara, B. R. Ojha, U. R. Rosyara, D. Bhandari and M. R. Bhatta. 2007. Major Gene Controls of Field Resistance to Spot Blotch in Wheat Genotypes 'Milan/Shanghai \#7' and 'Chirya.3'. Plant Disease,
91: 692-697.

Prashant, G. and J. Kumar. 2010. Genetics of resistance to spot blotch, Bipolaris sorokiniana, in bread wheat. SABRAO Journal of Breeding and Genetics, 42: 74-83.

Ragiba, M., K. V. Prabhu and R. B. Singh. 2004. Recessive genes controlling resistance to Helminthosporium leaf blight in synthetic hexaploid wheat. Plant Breeding, 123: 389-391.

SAS Institute. 2011. SAS 9.3 Software. SAS Institute Inc., Cary, North Carolina, United States.

Sharma, R. C., H. J. Dubin, M. R. Bhatta and R. N. Devkota. 1997a. Selection for Spot Blotch Resistance in Four Spring Wheat Populations. Crop Science, 37: 432.

Sharma, R. C., H. J. Dubin, R. N. Devkota and M. R. Bhatta. 1997b. Heritability estimates of field resistance to spot blotch in four spring wheat crosses. Plant Breeding, 116: 64-68.

Sharma, R. C., B. Pandey-Chhetri and E. Duveiller. 2006. Heritability estimates of spot blotch resistance and its association with other traits in spring wheat crosses. Euphytica, 147: 317-327.

Singh, D., R. V. Singh, A. K. Singh and B. N. Singh. 1998. Identification and inheritance of resistance to foliar blight of wheat. in: Duveiller E, H.J. Dubin, J. Reeves \& A. McNab (Eds.), Helminthosporium Blights of Wheat: Spot Blotch and Tan Spot Workshop. El Batán, CIMMYT, Mexico, p. 259-262.

Singh, R. K. and B. D. Chaudhary. 1995. Biometrical methods in quantitative genetic analysis. Kalyani Publishers, Delhi, India, p. 103-127.

Warner, J. N. 1952. A Method for Estimating Heritability1. Agronomy Journal, 44: 427.

Zaazaa, E., M. A. Hager and E. F. El-Hashash. 2012. Genetical analysis of some quantitative traits in wheat using six parameters genetic model. American-Eurasian Journal Of Agricultural \& Environmental Sciences, 12: 456-462. 